\title{
Automatizētās datu apstrādes sistēmā esošo datu kontrole (Kriminālprocesa likuma 219. pants): nacionālie un starptautiskie piemērošanas aspekti
}

\author{
Dr. iur. Uldis Kinis \\ ORCID: 0000-0002-5573-9887 \\ Rìgas Stradina universitāte, Latvija \\ uldis.kinis@rsu.lv \\ Mg. iur. Nikita Sinkevičs \\ ORCID: 0000-0001-5997-1379 \\ Rìgas Stradina universitāte, Latvija \\ nikita.sinkevics@gmail.com
}

\section{Kopsavilkums}

Raksta tapšanas ideja ir saistita ar Valsts policijas iesniegto priekšlikumu Tieslietu ministrijas Kriminālprocesa ekspertu pastāvīgajai darba grupai par grozỉjumiem Kriminālprocesa likuma 219. panta otrajā daḷā. Kriminālprocesa likuma 219. pants "Automatizētās datu apstrādes sistēmā esošo datu kontrole" būtībā ir analogs Kibernoziegumu konvencijas 19. pantam, kas uzliek dalībvalstīm pienākumu pienememt tādus tiesību aktus, kas atvieglotu to teritorijā esošo sistēmu pārmeklēšanu. Priekšlikuma būtība: atteikties pantā no nacionālās teritoriālās piemērošanas klauzulas, jo tā ierobežojot policijas iespējas iegūt pierādījumus, ja no pārmeklējamās sistēmas ir iespējams likumīgi piekḷūt datiem, kas glabājas sistēmās, kas atrodas ārpus Latvijas Republikas teritorijas. Citiem vārdiem sakot, idejas būtỉba ir mainīt panta piemērošanas jurisdikciju no nacionāli teritoriālās uz pārrobežu.

Diskusija par to, vai vienai dalībvalstij ir tiesības veikt datu sistēmu pārmeklēšanu citā dalībvalstī, notiek jau kopš Kibernoziegumu konvencijas piennemšanas. Turklāt tā turpināsies vismaz līdz Konvencijas otrā Papildprotokola pieņemšanai, kur būtu jāatrisina jautājumi ar pārrobežu sistēmu pārmeklēšanu un datu izṇemšanu. Rakstā tiks analizēts, vai un kā situācija, ìpaši saistībā ar jurisdikciju kriminālprocesā, pēc Kibernoziegumu konvencijas un Kriminālprocesa likuma pien,emšanas ir mainījusies, un tiks sniegti priekšlikumi, kā efektīvāk būtu risināma problēma, kuru aktualizējusi Valsts policija. 
Uldis Kinis, N̦ikita Sinkevičs. Automatizētās datu apstrādes sistēmā esošo datu kontrole

(Kriminālprocesa likuma 219. pants): nacionālie un starptautiskie piemērošanas aspekti

Atslēgvārdi: datu kontrole, automatizētā datu apstrādes sistēma, Kibernoziegumu konvencija, pierādījumi kriminālprocesā, suverenitāte, krimināljurisdikcija, datu pārmeklēšana un izṇemšana.

\section{levads}

Kriminālprocesa likuma (turpmāk - KPL) 219. pants "Automatizētās datu apstrādes sistēmā esošo datu kontrole" sastāv no četrām dạ̣ām (Kriminālprocesa likums, 2005). Pirmajā dạ̣ā sniegta automatizētās datu apstrādes sistēmā (turpmāk - ADAS) esošo datu kontroles legāldefinīcija, otrajā daḷā reglamentēta subjektīvās jurisdikcijas teritoriālās piemērošanas klauzula, trešajā dạ̦ā paredzētas procesa virzìtāja tiesības pieprasìt nodrošināt pārmeklējamo datu veselumu un nepieejamību citām personām. Savukārt ceturtajā dạ̣ā ir noteikta izṇemto datu juridiskā kontrole un kārtība.

2020. gadā Valsts policija (turpmāk - VP) vērsās ar priekšlikumu veikt grozījumus Kriminālprocesa likuma 219. panta "Automatizētās datu apstrādes sistēmā esošu datu kontrole" otrajā daḷā: "Ja ir pamats uzskatīt, ka meklētie dati (informācija) tiek uzglabāti citā Latvijas teritorijā esošā sistēmā, kurai var piekḷūt autorizēti, izmantojot izmeklēšanas tiesneša lēmumā minēto sistēmu, jauns lēmums nav nepieciešams." VP lūdz izslēgt no panta daḷas vārdus "Latvijas teritorijā esošā". Priekšlikuma iesniedzēji pēc būtības lūdz izslēgt no normas subjektīvās teritoriālās jurisdikcijas piemērošanas klauzulu. Pēc priekšlikuma autoru viedokḷa, tieši šì teritoriālās jurisdikcijas piemērošanas klauzula liedzot policijai veikt pienācīgas kvalitātes procesuālās darbības elektronisko pierādỉjumu iegūšanā no kratîšanai pakḷautajām ierīcēm, ja piekḷuve attālinātiem datiem neatkarīgi no to geogrāfiskās atrašanās vietas būtu iespējama bez speciālu drošības līdzekḷu izmantošanas.

Krimināltiesību pētnieku vidū diskusija par šo jautājumu jau norit, kopš internets, uzsākot pasaulē savu uzvaras gājienu, radīja globālo informācijas telpu, kas tiek aktīvi izmantota arī dažādu nelikumīgu darbību veikšanai. 1989. gadā tika pieṇemta Eiropas Padomes Rekomendācija Nr. 89(9) par datorsaistītiem noziegumiem (Council of Europe, 1990) un 1995. gada Rekomendācija R(95)13 par kriminālprocesuālo likumu piemērošanas problemātiku saistībā ar informācijas tehnolog̣ijām (Council of Europe, 1995). Turpinot šo darbu, 1997. gadā Eiropas Padome uzsāka darbu pie Kibernoziegumu konvencijas, kas noslēdzās ar 2001. gada 23. novembrī Budapeštā parakstīto Kibernoziegumu konvenciju (turpmāk - KNK) (Council of Europe, 2001), kurai Latvija pievienojās 2007. gadā. KNK līdz šim ir vienīgais starptautiskais līgums, kurš reglamentē kibernoziegumu apkarošanas materiālos, procesuālos, nacionālos un starptautiskās sadarbības aspektus krimināllietās. KNK 19. pants "Uzglabāto datu pārmeklēšana un pārṇemšana” ir tiešs priekštecis Kriminālprocesa likuma 219. pantam. Tāpēc tas tika izstrādāts, lai atbilstu KNK 19. pantā izvirzìtajām prasībām.

Kopš KNK pien̦emšanas ir pagājuši vairāk nekā 19 gadi, tāpēc raksta mērḳis ir izpētìt, vai straujā informācijas tehnologiiju attīstība ir mainījusi to KNK normu, kas saistīta ar elektroniskās vides pārmeklēšanu un tās piemērošanas jurisdikciju. Vai pasaulē 
Uldis Kinis, Nikita Sinkevičs. Automatizētās datu apstrādes sistēmā esošo datu kontrole

(Kriminālprocesa likuma 219. pants): nacionālie un starptautiskie piemērošanas aspekti

mainijusies izpratne par jurisdikcijas pamatiem? Kā KNK dalībvalstis gan Austrumos, gan arī Rietumos regulē šo procesuālo instrumentu, un kādas ir šì instrumenta piemērošanas robežas? Vai, ieviešot šo priekšlikumu, tiktu sasniegts tā mērḳis: veikt no kratīšanai pakḷautās sistēmas ar sistēmā pieejamiem identifikatoriem piekḷuvi attālinātiem datiem neatkarīgi no to fiziskās vai virtuālās atrašanās vietas?

Lai izvērtētu šì priekšlikuma būtību, rakstā tiek analizēta tikai Kriminālprocesa likuma 219. panta pirmā daḷa - ADAS pārmeklěšanas legāldefinīcija - un šì panta otrā daḷa, kas satur tās piemērošanas teritoriālo klauzulu, jo tieši minētās normas ir svarīgas, lai izvērtētu ar VP priekšlikumu saistīto problemātiku un iespējamās sekas. Raksta sagatavošanā analizēti arī citi KNK dalībvalstu kriminālprocesa likumi par ADAS pārmeklēšanu un tās piemērošanas robežām. Tāpat pētỉjuma sagatavošanā izmantoti citi juridiskās literatūras avoti un ES normatīvie akti. Raksta nobeigumā izvirzīti priekšlikumi šì procesuālā instrumenta efektīvākai piemērošanai.

Raksta sagatavošanā izmantota salīdzinošā tiesību metode un tiesību normu interpretācijas metodes: vēsturiskā, gramatiskā, sistēmiskā un teleologiiskā metode.

\section{KPL 219. panta vēsturiskā attīstība}

“(1) Automatizētās datu apstrādes sistēmas (tās daḷas), tajā uzkrāto datu, datu vides pārmeklēšanu un piekḷuvi tai, kā arī izṇemšanu bez šīs sistēmas vai datu īpašnieka, valdītāja vai turētāja ziṇas kriminālprocesā veic, pamatojoties uz izmeklēšanas tiesneša lēmumu, ja ir pamats uzskatìt, ka konkrētajā sistēmā esošā informācija var saturēt ziṇas par pierādāmajos apstākḷos ietilpstošajiem faktiem.

(2) Ja ir pamats uzskatīt, ka meklētie dati (informācija) tiek uzglabāti citā Latvijas teritorijā esošā sistēmā, kurai var piekḷūt autorizēti, izmantojot izmeklēšanas tiesneša lēmumā minēto sistēmu, jauns lēmums nav nepieciešams."

KPL tika pieṇemts 2005. gada 21. aprīlī un stājās spēkā 2005. gada 1. oktobrī, un tajā bija iekḷauts 219. pants "Elektroniskajā informācijas sistēmā esošo datu kontrole" . Savukārt ar 2009. gada 12. marta likumu par Grozỉjumiem Kriminālprocesa likumā minētais pants tika definēts kā "Automatizētās datu apstrādes sistēmā esošo datu kontrole" (Kriminālprocesa likums, 2005). Tomēr, izṇemot elektroniskas informācijas sistēmas aizstāšanu ar automatizētu datu apstrādes sistēmu, citi grozijumi panta pirmajā un otrajā daḷā netika veikti.

Nepieciešamību ietvert Kriminālprocesa likumā šādu normu noteica gan nacionālā procesuālā nepieciešamība, gan arī Eiropas Padomes Rekomendācijas, kā arī 2001. gadā pieñemtā Kibernoziegumu konvencija un tās protokols. Minētie dokumenti rekomendēja dalībvalstīm Kriminālprocesa likumā ieviest instrumentus, kas efektivizētu valstu cīṇu pret kibernoziegumiem un tai pašā laikā garantētu aizsardzību pret personu pamattiesību nepamatotu ierobežošanu. Par pirmo starptautisko avotu saistībā ar elektroniskās vides pārmeklēšanu uzskatāma jau minētā Eiropas Padomes Rekomendācija R(95)13 (Council of Europe, 1995), kur pirmo reizi starptautiskas vadlīnijas formā tika definēts jauns kriminālprocesuālais instruments - sistēmā uzglabāto datu meklēšana un pārṇemšana 
Uldis Kinis, N̦ikita Sinkevičs. Automatizētās datu apstrādes sistēmā esošo datu kontrole (Kriminālprocesa likuma 219. pants): nacionālie un starptautiskie piemērošanas aspekti

(angḷu val. search and seizure). Tās saturs definēts Rekomendācijas Pielikuma 1. punkta 2. apakšpunktā, kur norādīts, ka kriminālprocesa likumiem ir jāațauj izmeklēšanas iestādēm veikt datorsistēmu pārmeklēšanu un datu izṇemšanu līdzvērtīgi tradicionālajai. Turklāt 1.3. punktā uzsvērts, ka "izmeklēšanas iestādēm ir tiesības paplašināt pārmeklēšanas objektus un pakḷaut tai arī citas savstarpēji tīklā savienotas to jurisdikcijā esošas datorsistēmas". Tomēr Eiropas Padome secināja, ka dalïbvalstis nav visai aktīvas šo rekomendāciju ieviešanā, tāpēc tika nolemts uzsākt darbu pie Kibernoziegumu konvencijas. 1996. gadā tika izveidota Eiropas Padomes Kibernoziegumu ekspertu komiteja. Tās uzdevums bija izstrādāt KNK, kas tika parakstīta 2001. gada 23. novembrī Budapeštā (Council of Europe, 2001). Vienlaikus ar KNK tika pienemts Kibernoziegumu konvencijas Paskaidrojošais ziņojums (turpmāk - KNK PZ) (Council of Europe, 2001). Lìdz šim brīdim tas ir arī vienīgais saistošais starptautiskais līgums kibernoziegumu apkarošanai, un Latvija tam pievienojās 2007. gadā. Jānorāda, ka arī Eiropas Savienībā Konvencijas pien,emšanas brīdī, izṇemot Komisijas politikas dokumentu (European Commission, 1996), šajā jomā nebija speciāla regulējuma. Tāpēc KNK PZ 8. punktā ir uzsvērts, ka informācijas tehnologiju un sakaru pakalpojumu savienojums radijis jaunu kopigu telpu, kuru sauc par kibertelpu. Tā rada iespēju veikt pārrobežu rakstura nodarījumus, kas nereti nepakḷaujas nacionālo tiesību jurisdikcijai. Tādēl ir nepieciešami starptautiski centieni, lai nostiprinātu Eiropas Padomes Rekomendācijā (89)9 minēto, ka datorsaistītiem noziegumiem ir pārnacionāls raksturs, ka cinnai pret šiem nodarījumiem nepieciešams uzlabot starptautisko tiesisko sadarbỉbu.

Panta pamatā ir vispāratzītā un plaši izmantotā kriminālprocesuālā darbība kratîšana (KPL 179. pants). Tās mērḳis ir iegūt materiālus (taustāmus) pierādījumus kriminālprocesā (sk. KNK PZ 186. punktu). Kratī̌̌ana ir patstāvīga izmeklēšanas darbība, kurai raksturīga augsta iejaušanās pakāpe personas dzīvē (Meikališa, 2019). Šĩ iejaukšanās pamattiesību kontekstā saistāma ar personas tiesībām uz privātumu. KNK izstrādātā panta mērḳis ir panākt elektroniskās vides pārmeklēšanai tādu pašu efektivitāti, kā to var sasniegt, pārmeklējot mājokḷus un izṇemot taustāmus pierādỉjumus savā nacionālās valsts teritorijā situācijās, kad iesaistīti vietējie sakaru pakalpojumu sniedzēji (sk. KNK PZ 188. punktu). Kāpēc bija jāveido jauns regulējums?

Galvenais iemesls ir tas, ka pastāv divu veidu dati: 1) dati, kas ir saglabāti ADAS un atrodas pārmeklējamā ierīcē, un 2) attālināti pieejamie dati, kuri ir savienoti ar sistēmu, bet atrodas citā geogrāfiskajā vietā esošā ADAS. ADAS saglabātos datus var iegūt kratīšanas procesā, izṇemot dažādus datu nesējus, taču nevar attālināti iegūt datus no sistēmām, kas atrodas ārpus valsts jurisdikcijas, jo procesa virzītājs ir tiesīgs rīkoties tikai nacionālās valsts teritorijā. Kaut arī kratīšana un darbības pēc juridiskās kontroles līmeña un piemērošanas principiem ir līdzīgas, tomēr elektroniskās vides pārmeklēšana ir daudz sarežǵîtāka darbība, jo galvenais šĩs aktivitātes uzdevums ir iegūt lietā nepieciešamos elektroniskos pierādījumus, kas var atrasties dažādos datu nesējos. Tradicionālajā kratīšanā tiek pārmeklēta fiziska telpa, objekti, savukārt elektroniskās vides pārmeklēšana nav saistīta tikai ar dažādu datu nesēju pārmeklēšanu un izṇemšanu, bet arī ar 
Uldis Kinis, N̦ikita Sinkevičs. Automatizētās datu apstrādes sistēmā esošo datu kontrole

(Kriminālprocesa likuma 219. pants): nacionālie un starptautiskie piemērošanas aspekti

attālināti pieejamo datu iegūšanu no pārmeklējamās datorsistēmas. Turklāt elektroniskie pierādījumi ir viegli gaistoši, tādēl to iegūšana un saglabāšana procesa virzītājiem nereti ir lıoti darbietilpīgs un tehniski sarežgìts process. Eiropas Padomes dalībvalstis pārstāv dažādas tiesību sistēmas, līdz ar to arī kriminālprocesuālais regulējums ir atšḳirīgs. Tāpēc KNK 19. panta mērḳis bija panākt, lai dalībvalstis, izmeklējot kibernoziegumus, padarītu šì procesuālā līdzekḷa piemērošanu efektīvu nacionālās valsts teritorijā, proti, ar vienu kompetentas amatpersonas lēmumu par ADAS pārmeklēšanu un datu izṇemšanu to attiecinātu uz jebkuru valsts teritorijā esošu ADAS, ja šādiem datiem var likumīgi piekḷūt no pārmeklējamās ADAS. Jābūt iespējai nekavējoties paplašināt meklēšanu vai līdzīgi piekḷūt otrai sistēmai un iegūt tajā glabātus datus. Tāpēc KPL 219. panta mērḳis ir tieši un nesaraujami saistīts ar KNK 19. pantā sniegto definīciju, jo šī norma KPL esošajā redakcijā tika iekḷauta ar mērḳi, lai Latvija varētu pievienoties KNK, jo tikai pēc normatīvā regulējuma attiecīgo grozỉjumu Krimināllikumā un KPL pien,emšanas Latvija 2007. gada 14. aprīlī pievienojās KNK. Tāpēc, lai noskaidrotu šajā pantā reglamentēto darbību mērḳi un piemērošanas robežas, ir nepieciešams to analizēt kopsakarā ar KNK 19. pantu "Uzglabāto datu meklēšana un pārṇemšana".

Tā kā pantam ir četras daḷas, tiks atzīmētas galvenās panta juridiskā kodola sastāvdaḷas:

1) normatīvie akti, kas pilnvaro tās kompetentās institūcijas pārmeklēt vai līdzīgi piekḷūt ADAS vai tās dalıiai, kas atrodas tās teritorijā;

2) piekḷuve citas puses teritorijā esošai ADAS vai tās daḷai, ja no pārmeklējamās ADAS ir iespējams meklētajiem datiem likumīgi piekḷūt vai arī tie jau ir pieejami (respektīvi, ar vienu tiesas lēmumu var paplašināt meklēšanu uz jebkuru valsts teritorijā esošu ADAS);

3) jāuzliek par pienākumu atbildīgajām personām nodrošināt šo datu aizsardzību;

4) juridiskā kontrole - lēmumu var pienemt tikai tiesnesis.

KNK 1. pants datus iedala trijos juridiskajos līmeños: ir plūsmas dati (angḷu val. traffic data); ar abonentu saistitie dati (angḷ val. subscriber data) un satura dati (angḷu val. content data). Katram no šo datu veidiem ir savs juridiskais kontroles limmenis. Uzkräto datu saglabāšanu reglamentē KNK 16.-17. pants. Savukārt satura datu kontroli - uzglabāto datu meklēšanu un pārṇemšanu - reglamentē KNK 19. pants. Latvijas tiesību sistēmā Elektronisko sakaru likuma 1. panta $44^{2}$. punktā tiek izdalīti "noslodzes dati, atrašanās vietas dati un ar tiem saistìti dati, kas nepieciešami, lai identificētu abonentu vai lietotāju" (Elektronisko sakaru likums, 2004), kas atbilst KNK pirmajai un otrajai datu grupai. Šo datu ieguvi reglamentē KPL 191. pants, kur pieprasijumu par datu iesaldēšanu, kas atrodas pie pakalpojumu sniedzēja, veic procesa virzìtājs. Savukārt datu izsniegšanai ir nepieciešama juridiska kontrole. Tādējādi KNK izstrādātāji un arī Latvijas likumdevējs ir nošḳīis šo divu pirmo datu grupu iegūšanas juridiskās prasības no sistēmā saglabātu datu, kas pēc būtības ir satura dati, kontroles un izn,emšanas. Protams, abos gadijumos tiek veikta personu datu apstrāde un ierobežots privātums, taču, piemērojot KPL 219. pantu, š̃ iejaukšanās privātumā ir daudz būtiskāka, tāpēc lielākajā daḷā pasaules valstu lēmumu par datu 
Uldis Kinis, Nikita Sinkevičs. Automatizētās datu apstrādes sistēmā esošo datu kontrole (Kriminālprocesa likuma 219. pants): nacionālie un starptautiskie piemērošanas aspekti

kontroli pieņem tiesas amatpersona (Latvijā tas ir izmeklēšanas tiesnesis). A. Lieljuksis norāda, ka ADAS esošo datu kontrole ir speciālā izmeklēšanas darbība, kuras mērḳis ir bez ìpašnieku, valdītāju vai turētāju zin̦as, bet ar izmeklēšanas tiesneša ațauju iegūt zin̦as par pierādāmos apstākḷos ietilpstošiem faktiem, to izṇemšanu un tiesības pieprasīt citiem lietotājiem saglabāt uzkrāto datu veselumu un nodrošināt to nepieejamību (Lieljuksis, 2019). Tādējādi satura datu iegūšana kriminālprocesā tiek īpaši aizsargāta.

KNK PZ 195. punktā ir skaidri definēta normas piemērošanas teritoriālā klauzula, proti, ka šo normu "nevar izmantot, lai veiktu pārrobežu pārmeklēšanu, iegūstot elektroniskos pierādijjumus no sistēmām, kas atrodas citu valstu teritorijās". Tomēr kopš KNK pien̦emšanas ir pagājuši vairāk nekā 19 gadi, līdz ar to ir svarīgi noskaidrot, kā tiek iedzīvināta KNK un vai ir mainījusies šì panta teritoriālās jurisdikcijas piemērošanas klauzula. Tādēl ir svarīgi saprast, kāpēc Eiropas Padomes Kibernoziegumu komitejas eksperti vienojās un dalībvalstis atbalstīja tieši šādu KNK 19. panta tekstu. Tāpēc ir jāapskata KNK definētā jurisdikcija un tās piemērošanas interpretācija.

\section{Jurisdikcija un diskusijas par tās piemērošanas robežām}

Termins "jurisdikcija” ir cēlies no latīnu vārda "jurisdictio". Romiešu tiesībās ar to apzīmēja juridisku varu - tiesību noteikt, regulēt un piemērot likumus savas valsts teritorijā (Ķinis, 2015). Attīstoties krimināltiesību zinātnei, Hārvarda Universitātē 1935. gadā tika izstrādāta paplašinātā teritoriālā krimināljurisdikcijas doktrīna, kas balstīta uz pieciem kritērijiem: 1) teritoriālo jurisdikciju (objektīvo, subjektīvo); 2) objektīvo personālo jurisdikciju; 3) aizsardzības principu; 4) seku jurisdikciju (pasīvo personālo jurisdikciju) un 5) universālo jurisdikciju. Kaut arī šīs doktrīnas sagatavošana palika tikai projekta līmenī, tomēr tā ir atstājusi milzīgu iespaidu uz krimināljurisdikcijas attīstību visā pasaulē (Svantesson, 2015).

Jau KNK ekspertu grupā par jurisdikcijas pamatiem, principiem un robežām notika lıti sarežğîtas diskusijas, kuru rezultātā eksperti vienojās, ka kibernoziegumu jurisdikcijas regulējumā ir ietverami visi iepriekšminētie Hārvarda Universitātes projekta jurisdikcijas principi. Jāuzsver, ka arī 2000. gadā bija internets un globālie informācijas pakalpojumu sniedzēji, kuru pakalpojumi tika sniegti jebkurā vietā, kur pieejams internets. Šajās diskusijās tika izvērtēti visi iepriekšminētie jurisdikcijas kritēriji un atzīts, ka kibernoziegumu jurisdikcijas pamats ir teritoriālā jurisdikcija un ka jurisdikciju (noteikt, piemērot, iztiesāt) var piemērot tiktāl, ciktāl tā nepārkāpj citu valstu suverēnās tiesības uz jurisdikciju. Savukārt, ja būtu izvirzīti citi jurisdikcijas principi, darbs pie KNK, visticamāk, tiktu pārtraukts un beigtos bez rezultāta. Tādējādi KNK jurisdikcijas kodols ir teritoriālās (subjektīvās un objektīvās, jeb paplašinātās) jurisdikcijas princips, kura neatṇemama sastāvdaḷa ir dalībvalstu suverenitāte.

Saskaņā ar KNK 22. pantu dalībvalstij ir jāpien,em tāds regulējums, lai paredzētu jurisdikciju par KNK pirmajā nodậa noteiktajiem kibernoziegumiem savas valsts 
Uldis Kinis, N̦ikita Sinkevičs. Automatizētās datu apstrādes sistēmā esošo datu kontrole

(Kriminālprocesa likuma 219. pants): nacionālie un starptautiskie piemērošanas aspekti

teritorijā Savukārt, piemērojot paplašinātās jurisdikcijas doktrīnu, attiecināt to arī uz 1) karoga principu (kug̣i, lidmašīnas); 2) personas principu; 3) dubultās kriminalitātes principu; 4) ārpus jebkuras valsts teritoriālās jurisdikcijas principu. Tomēr, kā ir uzsvērts juridiskajā literatūrā, neviena dalībvalsts rīcība nedrīkst pārkāpt citas valsts teritoriālo jurisdikciju (Kinis, 2015) jeb, citiem vārdiem sakot, suverenitāti (Koops, 2006). Taču raksts nesasniegtu savu mērkị, ja netiktu analizēti arī citu KNK dalībvalstu kriminālprocesuālie regulējumi saistībā ar ADAS pārmeklēšanu un datu izṇemšanu. Proti, vai dalībvalstis paredz procesa virzitājam tiesības veikt datu pārmeklēšanu un izṇemšanu no ārpus valsts teritorijas esošām sistēmām.

\section{Automatizētās datu apstrādes sistēmā esošo datu kontroles regulējuma salīdzinošā kriminālprocesuālā analīze}

Šajā raksta daḷā tiek veikta atsevišku valstu, kuras ir ratificējušas KNK (Council of Europe, 2020) - Austrijas, Bulgārijas, Francijas, Igaunijas, Polijas, Lietuvas, Norvēǵijas, Vācijas, Ukrainas, Rumānijas, Slovēnijas, Slovākijas, Portugāles, Zviedrijas un Spānijas -, kriminālprocesuālo regulējumu un pieeju attiecībā uz datu kontroli ārvalstu ADAS salīdzinošā analīze.

Austrija. No Kriminālprocesuālā kodeksa izriet, ka nav atsevišḳas normas, kurā būtu norādìts, ka kodekss darbojas tieši un tikai valsts iekšienē. Atbilstoši šì kodeksa 25. panta pirmajai daḷai, ja noziedzīgā nodarījuma izdarī̌̌anas vieta atrodas ārpus valsts vai šo vietu nevar noteikt, tad izšḳirošā nozīme ir vietai, kur noziedzīgā nodarījuma sekas iestājās vai tām vajadzēja iestāties. Savukārt no šī panta septītās daḷas izriet: ja noziedzīgais nodarījums bija noticis vai tam bija jānotiek citā Eiropas Savienības dalībvalstī, prokuratūrai ir pienākums nekavējoties par to paziņot citai dalībvalstij, izņemot gadījumus, kad likumpārkāpumu regulē nacionālā jurisdikcija. Kriminālprocesuālā kodeksa 115. panta pirmā dal̦a regulē priekšmetu izņemšanu un netiek paredzēts, ka šiem priekšmetiem būtu jāatrodas tieši valsts teritorijā. Jāatzīmē, ka no kodeksa 111. panta otrās dalıas izriet, ka katrai personai, kas ir tiesīga rīkoties ar datu nesēju, ir pienākums sniegt pieeju datiem (Rechtsinformationssystem des Bundes, 2020).

Bulgārija. No Bulgārijas Kriminālprocesa kodeksa 172. panta pirmās daḷas izriet, ka kriminālprocesa izmeklēšanā var tikt piemērota speciālā datu pārbaude. Savukārt atbilstoši šì panta trešajai daļai likumā noteiktajos gadỉjumos datoru un informācijas pakalpojumu sniedzējiem ir pienākums sniegt atbalstu tiesai un pirmstiesas izmeklēšanas iestādēm datu vākšanā un reǵistrācijā, izmantojot speciālos tehniskos līdzekḷus (Наказателно-процесуален кодекс, 2020).

Francija. Kriminālprocesa kodeksa pants “706-102-1" paredz iespēju bez ieinteresēto personu piekrišanas piekḷūt datoru datiem, tos reǵistrēt, glabāt un pārsūtìt. (Legifrance, 2020). Tāpat arī šajā pantā nav norādes par konkrētu teritoriju, kur datoram vai tā datiem jāatrodas. Ja ir noteikts, ka informācijas sistēma atrodas ārvalstī, tad datus 
Uldis Kinis, Nikita Sinkevičs. Automatizētās datu apstrādes sistēmā esošo datu kontrole

(Kriminālprocesa likuma 219. pants): nacionālie un starptautiskie piemērošanas aspekti

no šīs sistēmas var iegūt, ievērojot starptautiskajās saistībās ietvertos nosacỉjumus (Legicoop, 2020).

Igaunija. No Kriminālprocesa kodeksa $126 .{ }^{7}$ panta izriet, ka kriminālprocesa ietvaros var veikt informācijas pārtveršanu vai apskati publiskajos elektroniskajos sakaru tìklos. Šajā normā nav norādes uz teritoriju, kurā jāatrodas elektroniskajam sakaru tīklam (Riigi Teataja, 2020). Ja datu meklēšanas vai datora ekspertīzes laikā no esošās sistēmas var likumiski piekḷūt citai sistēmai bez šìs sistēmas uzlaušanas vai drošības nosacỉjumu pārkāpuma, tad tiesībaizsardzības iestādes var turpināt un paplašināt meklēšanu konkrētajā sistēmā (Legicoop, 2020).

Polija. No Kriminālprocesa kodeksa 241. panta izriet, ka kriminālprocesā var tikt veikta datu kontrole (Kancelaria Sejmu, 2020), taču šajā pantā nav norādes uz informācijas sistēmas teritoriālo piekritību. Likumā nav regulēti jautājumi, kuri ir saistīti ar datu pārmeklēšanu ADAS (Legicoop, 2020).

Lietuva. Atbilstoši Kriminālprocesa kodeksa 154. pantam kriminālprocesa ietvaros var tikt veikta datu kontrole elektroniskajos sakaru tīklos. Šajā normā nav atsevišķas norādes uz teritoriju, kur jāatrodas datiem un elektroniskajam sakaru tīklam. Savukārt saskaṇā ar kodeksa 4. panta otro dalıu neatkarīgi no tā, kur noziedzīgais nodarījums tika izdarīts, kriminālprocess Lietuvas Republikas teritorijā notiek saskaṇā ar Lietuvas Republikas Kriminālprocesa kodeksu (Lietuvos Respublikos Seimas, 2020).

Norvēgija. Saskaṇā Kriminālprocesa likuma 216. pantu tiesa var atḷaut veikt publiski nepieejamās informācijas (datu) nolasī̌anu datorsistēmā vai lietotāja kontā, kas paredzēts tîkla sakaru un glabāšanas pakalpojumiem un pieder aizdomās turētajam, vai var tikt pien,emts, ka vin,š vēlas tos izmantot. Tāpat datu nolasī̌nana ietver sakarus, elektroniski saglabātus datus un citu informāciju par datorsistēmas vai lietotāja konta izmantošanu. Atbilstoši šĩ likuma 4. pantam likuma noteikumus piemēro ar ierobežojumiem, kas ir atzīti starptautiskajos tiesību aktos vai izriet no līguma ar ārvalsti (LOVDATA, 2020).

Vācija. Atbilstoši Kriminālprocesa kodeksa 100.b panta pirmajai daḷai bez attiecīgās personas ziṇas var iejaukties viñas izmantotajā informācijas tehnologiju sistēmā un no tās var apkopot datus (veikt meklěšanu tiešsaistē). Tāpat no ši kodeksa otrās nodaḷas izriet, ka šì kodeksa ietvaros veicamās izmeklēšanas darbības ir veicamas tieši Vācijas Federatīvās Republikas teritorijā (Bundesministeriums der Justiz und für Verbraucherschutz, 2020). Gadījumā, ja dati glabājas informācijas sistēmā, kura atrodas ārvalstī, un Vãcijas varas iestādes piekḷ̂̄st šiem datiem no Vācijas teritorijas, tad tas tiktu uzskatīts par ārvalsts suverēno tiesību pārkāpumu. Taču tas neattiecas uz tādiem ārvalstī esošajiem datiem, kuri ir publiski pieejami vai par kuriem ir saṇemta labprātīga personas, kurai ir tiesības datus izṇemt un veikt to pārraidi sistēmā, piekrišana. Citos gadỉjumos jāizmanto tiesiskās palīdzības lūguma mehānismi (Legicoop, 2020).

Ukraina. Saskaṇā ar Ukrainas Kriminālprocesa kodeksa 264. panta pirmo punktu var tikt veikta informācijas sistēmā vai tās dạ̦ās esošo ziṇu meklēšana un fiksācija, nodrošināta pieeja informācijas sistēmai vai tās dạ̦ām, kā arī ziṇu iegūšana bez ìpašnieka vai valdītāja piekrišanas, ja ir informācija par datu, kuriem ir nozīme pirmstiesas izmeklēšanā, 
Uldis Kinis, N̦ikita Sinkevičs. Automatizētās datu apstrādes sistēmā esošo datu kontrole

(Kriminālprocesa likuma 219. pants): nacionālie un starptautiskie piemērošanas aspekti

esamību informācijas sistēmā vai tās daḷā. Savukārt šì kodeksa pirmā panta pirmais punkts nosaka, ka kriminālprocess Ukrainas teritorijā tiek noteikts tikai ar Ukrainas kriminālprocesa normatīvajiem aktiem (Уголовный процессуальный кодекс, 2020).

Rumānija. Atbilstoši Kriminālprocesuālā kodeksa 168. panta astotajai dạ̣ai gadījumā, ja, pārmeklējot informācijas sistēmu, tajā tiek konstatēta cita informācijas sistēma un dati, kuriem var piekḷūt no šis sistēmas, tad prokurors nekavējoties pavēl datus saglabāt, nokopēt identificētos datus un nekavējoties lūgt pabeigt rīkojuma izpildi. Šajā normā nav norādes, kur dati teritoriāli atrodas. Tas ir saistīts ar to, ka tā ir attālināta operācija attālinātā vietā, un vienīgais, ko var darìt, - saglabāt datu kopiju (Legicoop, 2020).

Slovēnija. No Kriminālprocesuālā kodeksa 150. panta izriet, ka atsevišķos ar likumu noteiktajos gadijjumos kriminālprocesa ietvaros var tikt veikta elektronisko sakaru kontrole ar noklausǐšanos un ierakstī̌̌anu, kā arī visu elektronisko sakaru tīklos pārraidīto saziṇas veidu kontrole. Šajā normā nav norādes, kur informācijas sistēmai un datiem jāatrodas (Pravno-informacijski sistem, 1995).

Slovākija. Kriminālprocesa kodekss nepiel̦auj iespēju piekḷūt datiem, kuri atrodas citas valsts ADAS. Slovākijas varas iestādes norāda, ka piekḷūt šāda veida datiem ir iespējams, izmantojot Eiropas izmeklěšanas rīkojumu (Legicoop, 2020).

Portugāle. No Kibernoziegumu likuma 15. panta piektās daḷas izriet, ka tiesībaizsardzības iestādēm ir tiesības piekḷūt attālinātajām datorsistēmām no pārmeklējamā datora, ja pārmeklēšanas laikā tiek konstatēts, ka no šis sistēmas (kura sākotnēji tika pārmeklēta) var likumiski piekḷūt citai datorsistēmai (Procuradoria-Geral Distrital de Lisboa, 2009). Šì norma nenorāda, kur sistēmai fiziski jāatrodas - valsts teritorijā, ārzemēs, nezināmā atrašanās vietā (Legicoop, 2020).

Zviedrija. Varasiestādēm nav tiesību îstenot savas pilnvaras ārpus Zviedrijas teritorijas, kas nozīmē, ka datu pārmeklēšana nevar tikt īstenota citu valstu teritorijās (Legicoop, 2020).

Spānija. Atbilstoši Kriminālprocesuālā kodeksa 588. panta 3. punktam, ja sistēmas pārmeklēšanas laikā rodas pamatoti iemesli uzskatìt, ka meklējamie dati tiek glabāti citā datorsistēmā, meklēšana var tikt paplašināta, ja datiem var tiesiskā veidā piekḷūt caur sistēmu, kurā pārmeklēšana notiek. Nav atsevišķu norāžu, kur teritoriāli jāatrodas sistēmai. Tāpat parasta tehnisku ierīču iznememšana nedod tiesības piekḷūt šĩs iekārtas datiem bez tiesneša sankcijas (Legicoop, 2020).

No analīzes secināms, ka valstīm ir atšķirīga pieeja attiecībā uz datu kontroli ārvalstu ADAS.

\section{Krimināltiesiskās jurisdikcijas regulējums Latvijā}

Krimināllikuma 4. pantā "Krimināllikuma spēks ārpus Latvijas teritorijas" (Krimināllikums, 1998) ir iestrādāti visi KNK 22. pantā noteiktie jurisdikcijas principi. Krimināllikuma 4. pants ietver gan subjektīvo, gan arī objektīvo (paplašināto) teritoriālo jurisdikciju un no tās izrietošo personas jurisdikciju, karoga jurisdikciju, ārpus 
Uldis Kinis, N̦ikita Sinkevičs. Automatizētās datu apstrādes sistēmā esošo datu kontrole

(Kriminālprocesa likuma 219. pants): nacionālie un starptautiskie piemērošanas aspekti

jebkādas jurisdikcijas esošo teritoriju jurisdikciju, aizsardzības un seku jurisdikciju. Krimināllikums neparedz jurisdikcijas piemērošanai dubultās kriminālatbildības ierobežojumu, ko paredz lielākā dal̦a KNK dalībvalstu. Taču tas nekādā veidā nerada priekšrocības noziegumu izmeklēšanā, ja persona, kura pēc Krimināllikuma būs izdarījusi noziedzīgu nodarījumu, atradīsies ārpus valsts robežām, jo lielākā daļa KNK dalībvalstu šo principu gan Krimināllikumā, gan arī Kriminālprocesā joprojām uzskata par pamatu sadarbības izvērtēšanai.

Savukārt KPL 3. pants "Krimināllikuma spēks telpā" paredz: "Kriminālprocesa likums nosaka vienotu procesuālo kārtību visos kriminālprocesos, kurus par Latvijas jurisdikcijā esošiem noziedzīgiem nodarījumiem veic tam pilnvarotas personas" (Kriminālprocesa likums, 2005). Arī KPL komentāru A daḷā ir uzsvērts, ka pantā pausts vienots vispārīgs uzstādỉjums, ka visi kriminālprocesi Latvijas Republikā notiek saskaṇā ar vienotu KPL noteiktu kārtību (Strada-Rozenberga, 2019). Taču, tā kā lielākā dạ̣a nodarījumu ir saistīta ar globālu datu apriti, tad starp šiem pienākumiem un tiesībām veidojas paradokss. No vienas puses, valsts paredz kriminālatbildību un attiecina to uz jebkuru valsts teritorijā esošu subjektu, bet, no otras puses, apsūdzības pierādī̌nanai nepieciešamās kriminālprocesuālās darbības valsts ir tiesīga attiecināt tikai uz ADAS, kas atrodas Latvijas valsts teritorijā.

Lai arī spēkā ir vispārējie noteikumi par jurisdikcijas teritoriālo darbību, valsts cenšas noregulēt tiesiskās attiecības, kuras ir saistītas ar tiesisko kārtību, - arī tajos gadījumos, kad šīs attiecības veidojas ārpus tās robežām (Татаринов, 2019). Tāpēc KPL ir arī $C$ daḷa, kas tieši paredzēta starptautiskajai sadarbībai krimināltiesiskajā jomā un to reglamentē. Turklāt Kriminālprocesa likuma 673. panta pirmās daḷas 4. punkts paredz arī sadarbỉbu procesuālās darbības izpildē ārvalstīs (piemēram, izmantojot tiesiskās palīdzības lūgumus). Latvijas Republikas gadījumā atbilstoši Kriminālprocesa likuma 674. pantam Latvijas Republika var lūgt ārvalsti, izpildot krimināltiesiskās palīdzības lūgumu, piemērot Latvijas Republikā noteikto kriminālprocesuālo kārtību vai atsevišķus tās principus (Kriminālprocesa likums, 2005). Jāmin, ka atseviškłas valstis, piemēram, Vācija un Slovākija, norāda: lai piekḷutu ārvalstu ADAS datiem, nepieciešams izmantot starptautisko tiesību instrumentus, piemēram, jau minēto tiesiskās palīdzības lūgumu vai Eiropas rīkojuma orderi. Lìdzīgi ir arī citās valstīs.

\section{Suverenitāte un digitālā suverenitāte - teorētiska diskusija}

Suverenitāte ir starptautisko tiesību fundamentāls princips. Tallinn Manual pētnieki ir atzinuši, ka uz valsts teritorijā esošu kiberinfrastruktūru, ko veido valsts teritorijā esošās komunikācijas, ADAS, tīkli, kabel̦i, ir attiecināma nacionālās valsts suverēnā vara un no teritoriālās jurisdikcijas izrietošais suverenitātes princips (Schmitt, 2017). Tāpat Tallinn Manual eksperti norāda, ka valsts suverenitāte pār kiberinfrastruktūru rada divas sekas: 1) infrastruktūra tiek sargāta pēc nacionālās valsts likumiem; 2) valsts suverenitāte 
Uldis Kinis, N̦ikita Sinkevičs. Automatizētās datu apstrādes sistēmā esošo datu kontrole (Kriminālprocesa likuma 219. pants): nacionālie un starptautiskie piemērošanas aspekti

savā teritorijā aizsargā visu kiberinfrastruktūru neatkarīgi no tā, vai tā pieder personai vai valstij, un neatkarīgi no mērḳa, kāpēc infrastruktūra pastāv. Tallinn Manual eksperti, turpinot pētìt jautājumu par suverenitāti kibertelpā, atzina, ka valsts suverenitāte tiek iedalìta iekšējā un ārējā suverenitātē (Schmitt, 2017) un kiberinfrastruktūra attiecināma uz iekšèjo suverenitāti. Tādēl uz visu to, kas notiek attiecīgajā infrastruktūrā, valstij ir tiesības attiecināt savu jurisdikciju.

Turklāt suverenitāte attiecināma uz visiem kibertelpas līmeniem, tostarp fizisko, logisko un sociālo. Fizisko līmeni veido fiziskie tīkla elementi, ierīces, kabeḷi, rūteri, serveri, datori. Logisko - dati un protokoli, kas izmantojami, lai dati krustotos ar fizisko līmeni. Kibertelpas sociālo līmeni veido lietotāji, kas sniedz un izmanto informācijas pakalpojumus (Schmitt, 2017). Savukārt ārējā suverenitāte izriet no valsts suverenitātes, jo saskaṇā ar ANO Hartas 2(1) pantu valstis ir tiesībās vienlīdzīgas (Charter of the United Nations, 1948). No tā izriet, ka dalībvalstīm ir tiesības veikt aktivitāti kibertelpā ārpus tās teritorijas, ievērojot starptautiskās tiesības. Taču tās rīcības metodes nedrīkst pārkāpt citu valstu suverenitāti (Schmitt, 2017). Kiberaktivitāšu kontekstā par teritoriālās suverenitātes pārkāpumu uzskatāma darbỉba, kuru viena valsts ex officio veic citas valsts teritorijā esošiem objektiem vai personām (Schmitt, 2017). Turklāt vairums Tallinn Manual rokasgrāmatas sastādīšanā iesaistīto ekspertu uzskata, ka valstij nav suverenitātes pār datiem, kas atrodas ārpus valsts robežām, izṇemot starptautiskās tiesībās noteiktus gadījumus (Schmitt, 2017).

Var piekrist I. Ziemelei, ka šobrīd var runāt par suverenitātes paradoksu: suverenitāte kā a) augstākā vara pār konkrēto sabiedrību, b) absolūtā ārējā neatkarība, c) pilnīga tiesībspēja starptautiskās attiecībās (Ziemele, 2019). Jāpiekrīt arī Francijas Valsts padomes loceklei K. Bazì-Malorijai, ka valstis globālajā interneta pārvaldības procesā ir tikai viens no procesa partneriem (Bazy-Malaurie, 2018). Paradokss veidojas arī starp diviem valsts pienākumiem. No vienas puses, katras valsts pienākums ir apkarot kibernoziedzību, bet, no otras puses, tās pienākums ir arī ievērot starptautiskās tiesības un pienākumus, nepārkāpt citu valstu suverenitāti. Rezultātā kibernoziegumu apkarošana ir iespējama līdz zināmam brīdim, iekams darbība nenotiek vai arī netiek plānota cita starptautiska subjekta jurisdikcijā. Tāpēc svarīga ir Tallinn Manual ekspertu atziṇa, ka suverenitāte ne vien pieškirir tiesības, bet arī uzliek par pienākumu rīkoties (angḷu val. due diligence) apzinīgi un apturēt un novērst noziedzīgus nodarījumus, kas tiek veikti no valsts teritorijas (Schmitt, 2017). Tomēr ir jānorāda, ka līdz šim visi pūliṇi radīt efektīvāku starptautisko noregulējumu šajā jomā ir beigušies neveiksmīgi (Henriksen, 2019).

Jautājums par suverenitāti kibertelpā ir l̦oti sarežğìts, tāpēc ne visi piekrīt Tallinn Manual ekspertu viedoklim. Piemēram, profesors Dans Svantesons (Svantesson, 2017) uzskata, ka jurisdikcijas jēdzienā teritorialitāte kā suverenitātes komponente ir jānodala no valstiskuma (angḷu val. statehood) tiesībām noteikt jurisdikciju. D. Svantesons uzskata, ka būtu nepieciešams atteikties no teritorialitātes kā kiberjurisdikcijas kodola. Turklāt, pēc viņa domām, jurisdikcijas piemērošana būtu jāsaista ar apstākli, ka valsts tiesai, kas piemēro jurisdikciju, būtu jākonstatē un jāpamato būtiska saikne (angḷu val. substantial 
Uldis Kinis, Nikita Sinkevičs. Automatizētās datu apstrādes sistēmā esošo datu kontrole

(Kriminālprocesa likuma 219. pants): nacionālie un starptautiskie piemērošanas aspekti

connection) un leǵitīma interese (angḷu val. legitimate interest) jurisdikcijas piemērošanā (Svantesson, 2017). Tas dotu iespēju dalībvalstĩ veikt arī pārrobežu pārmeklēšanu, nepārkāpjot valstu suverenitātes robežas. Tomēr 2016. gada OCTOPUS konferencē viṇa idejas neatbalstīja lielākā dạ̣a konferences dalībnieku, tostarp nacionālo valstu kibernoziegumu eksperti, diplomāti un lielāko globālo informācijas pakalpojumu sniedzēju pārstāvji. Turklāt, apspriežot Kibernoziegumu komitejas "Cloud evidence group" (Council of Europe, 2016), tika atzìts, ka, piemērojot KNK, dalībvalstis vēl pilnā mērā neizmanto 1959. gada 20. aprị̣a Eiropas Padomes Konvenciju par savstarpējo palīdzību krimināllietās (Council of Europe, 1959) dotās iespējas. Piemēram, nacionālo valstu tiesību aizsardzības iestāžu pārstāvji pietiekami neizmanto tiešo komunikāciju ar globālajiem informācijas pakalpojumu sniedzējiem. Apspriežot šo ziņojumu, tika nolemts arī uzsākt darbu pie KNK Otrā papildprotokola.

2017. gadā Kibernoziegumu komiteja pieṇēma Vadlīniju Nr. 10, kurā daḷēji iestrādāta arì D. Svantesona ideja par būtisko saikni un legitīmo interesi (Council of Europe, 2017). Vadlīnija ir oficiālā KNK 18. panta interpretācija. KNK 18. pants noteic: "Puse pieņem tādus normatīvos aktus un veic citus nepieciešamos pasākumus, lai pilnvarotu tās kompetentās institūcijas pieprasìt personai tās teritorijā iesniegt konkrētus datus, kas atrodas personas ìpašumā vai kontrolē un kas ir saglabāti datorsistēmā vai datu uzkrāšanas vidē par abonentu." Vadlīnijā skaidrots, ka vietējo procesa virzìtāju lēmumi ir attiecināmi arī uz tādiem pakalpojumu sniedzējiem, kuriem nav savas pārstāvniecības nacionālajā valstī, taču kuru darbỉba valstī rada ekonomisku efektu. Tieši šis ekonomiskais efekts arī pamato procesuālas darbības būtisko saikni un leǵitimitāti. Taču KNK 18. pants attiecas tikai uz plūsmas un abonentu datu pieprasijumiem un to atklāšanu. Tie ir dati, kurus procesa virzītājs Latvijā var pieprasìt KPL 191. panta kārtībā. Līdz ar to šī Vadlīnija par abonentu datu pieprasī̌nanu ir piemērojama visiem digitālo platformu un pakalpojumu turētājiem un sniedzējiem, kuru darbỉba Latvijā rada ekonomisko efektu. Šie pieprasījumi ir attiecināmi arī uz ārvalstu jurisdikcijā esošajām datu glabātuvēm vai mākoṇdatnēm. Eksperti, kas uzskata, ka "valstīm nav suverenitātes pār datiem, kas pārraidīti no ārvalstīm vai saglabāti ārvalstīs esošās ADAS, un ka šie dati uzskatāmi par ārpus nacionālās suverenitātes esošiem", arī Tallinn Manual ekspertu vidū palika mazākumā (Schmitt, 2017).

KNK ir strukturēta trīs nodaḷās: 1) termini; 2) pasākumi, kas jāveic nacionālā līmenī (pasākumi, kas jāveic substantīvajās krimināltiesībās, un procesuālie līdzekḷi, kuri dalībvalstīm jāievieš saistībā ar KNK), un 3) starptautiskā sadarbība, kur katra no šīm nodaḷām sadalīta vairākās apakšnodaḷās. KNK19. pants ir ietverts otrās nodaļas 4. apakšnodaḷā, kas reglamentē tikai procesuālās darbības dalībvalstu teritorijā. Savukārt KNK 3. nodaḷas "Starptautiskā sadarbība" 2. apakšnodaḷā "Īpaši noteikumi” reglamentēta savstarpējā palīdzība attiecībā uz pagaidu pasākumiem. Apakšnodaḷa paredz šādas procesuālas darbības: 1) sistēmā uzkrāto datu operatīvu saglabāšanu (KNK 29. pants); 2) saglabātās datu plūsmas operatīvu atklāšanu (KNK 30. pants); 3) savstarpēju palīdzību attiecībā uz piekḷuvi uzkrātajiem datiem (KNK 31. pants); 4) pārrobežu piekḷū̌šnu 
Uldis Kinis, N̦ikita Sinkevičs. Automatizētās datu apstrādes sistēmā esošo datu kontrole

(Kriminālprocesa likuma 219. pants): nacionālie un starptautiskie piemērošanas aspekti

uzkrātajiem datiem ar piekrišanu vai tur, kur tie ir publiski pieejami; 5) savstarpēju palīdzību datu plūsmas vākšanai reālā laikā; 6) savstarpēju palīdzību attiecībā uz satura datu pārtveršanu; 7) 24/7 tìklu.

Savstarpējā palīdzība saistībā ar KPL 219. pantā paredzēto darbību ir reglamentēta KNK 31. pantā. KNK PZ 292. paragrāfā norādīts, ka šis pants piemērojams gadījumos, ja nepieciešama starptautiskā sadarbība. Piemērojot KNK 19. pantu nacionālās valsts robežās, lai pārṇemtu un atklātu ADAS saglabātus datus, kas atrodas Saṇēmēja puses teritorijā, Puse var lūgt šo darbỉbu veikt citai Pusei. Savukārt KNK 32. pants noteic, ka pārrobežu piekḷūšana ADAS uzkrātiem datiem ir piel̦aujama citā valstĩ tikai divos gadījumos: 1) ja uzkrātie dati ir publiski pieejami; 2) ja dati, kas iegūti no citas valsts teritorijas un izsniegti kompetentai iestādei, ir iegūti ar tādas personas aț̣auju, kurai ir likumīgas tiesības šos ADAS uzkrātos datus izsniegt kompetentai personai. KNK PZ 294. paragrāfā norādìts, ka šāda autorizēta persona varētu būt, piemēram, e-pastu pakalpojumu sniedzējs vai pats datu subjekts.

Tātad var secināt, ka KNK noteic, ka ADAS saglabāto datu pārrobežu pārmeklēšana un izṇemšana ir piel̦aujama tikai tad, ja tās nodrošināšanā tiek iesaistīta citas puses kompetentā institūcija vai amatpersona. Tādējādi KNK 19. pants uzskatāms par izmeklēšanas darbību, kuru dalībvalsts var veikt tikai nacionālās valsts ietvaros; šāda redakcija ir ietverta arī pašreizējā KPL 219. panta 2. daḷas regulējumā. Var piekrist A. Lieljuksim, ka, kaut arī normas darbība attiecas tikai uz Latvijas teritorijā izvietotām ADAS, kas geoogrāfiski izvietotas dažādās vietās, tomēr to varētu attiecināt arī uz Latvijā reǵistrētiem un uzṇēmējdarbību veicošiem ārvalstu uzṇēmumiem, kuru ADAS veido vienotu tīklu gan Latvijā, gan arī ārpus tās (Lieljuksis, 2019). Savukārt, ja, pārmeklējot šo sistēmu, bez papildu identifikatoriem iespējams piekḷūt datiem, kas atrodas citā valstī, tad procesa virzītājam ir jārīkojas KPL 83. nodaḷā noteiktā kārtībā un KNK 31. panta kārtībā.

\section{Eiropas Savienības digitālā suverenitāte}

Termins "tehnolog̣iskā vai digitālā suverenitāte" tiek attiecināts uz pasākumiem, kas nodrošina Eiropas Savienības līderību un stratēgisku autonomiju digitālā jomā, tostarp ekonomikā, kiberdrošībā, kibernoziegumu apkarošanā (Madiega, 2020). Eiropas Komisijas prezidente Urzula fon der Leiena norāda, ka digitālā suverenitāte apzīmē Eiropas spēju digitālā vidē veikt savas izvēles un rīcību, balstoties uz saviem likumiem un vērtībām. Ar to EK prezidente uzsvēra, ka Eiropai ir tiesības uz saviem likumiem, kas regulē interneta darbību (Komaitis, 2020). Kā norāda pētnieki, galvenais digitālās suverenitātes mērḳis ir kontrolēt datu plūsmas un protokolus Eiropas Savienībā (Floridi, 2020). Vācijas prezidentūra ES paredz izstrādāt kopīgu Eiropas pozīciju un to pārstāvēt ANO interneta pārvaldības organizācijās un Kibernoziegumu ekspertu komitejā un attīstīt plašu ES diplomātiju ES kibersankciju noteikšanai par ES normatīvo aktu un vērtību pārkāpšanu (Federal Foreign Office, 2020). Patiesībā šì diskusija ir tikai loğisks turpinājums Eiropas 
Uldis Kinis, N̦ikita Sinkevičs. Automatizētās datu apstrādes sistēmā esošo datu kontrole

(Kriminālprocesa likuma 219. pants): nacionālie un starptautiskie piemērošanas aspekti

vienotās juridiskās, ekonomiskās telpas izveidošanai. Galvenais šīs diskusijas iemesls ir radìt neatkarīgu digitālu vidi, samazinot atkarību no ASV un Kīnas (Federal Foreign Office, 2020).

Protams, ka, izveidojot vienoto tiesisko digitālo Eiropas Savienības telpu, Eiropas Savienība šajā teritorijā spēs daudz efektīvāk risināt arī pārrobežu ADAS pārmeklēšanas problēmu. Tomēr pastāv bažas, ka šādu ADAS pārmeklēšanu, kura fiziski atrodas citā ES dalībvalstì, Latvijas procesa virzītājs varēs veikt bez saskan,ošanas ar attiecīgās dalībvalsts amatpersonām. Protams, ka sadarbỉbas metodes var tikt vienkāršotas un process paātrināts, līdzīgi kā tas tiek paredzēts, izpildot jau spēkā esošos ES tiesiskās sadarbības instrumentus krimināllietās, tomēr ir ḷoti apšaubāmi, ka dalībvalstis būs gatavas atteikties no savas suverenitātes, lai apkarotu kibernoziedzību, īpaši, ja tā būs saistīta ar būtisku iejaukšanos citu valstu iedzīvotāju pamattiesībās un brīvībās, ko vairāku ES valstu konstitucionālās tiesas ir pasludinājušās par neaizskaramu valsts konstitucionālo kodolu.

Neapšaubāmi, ka ES digitālā suverenitāte nosaka un arī turpmāk noteiks ES prioritātes kibernoziegumu apkarošanā, jo īpaši saistībā ar pārrobežu piekḷuvi elektroniskajiem pierādỉjumiem (COM(2015) 185 final, 2015). Ir uzsākta diskusija par Eiropas Parlamenta un Padomes Regulu "Par Eiropas elektronisko pierādijumu sniegšanas un saglabāšanas rīkojumiem elektronisko pierādījumu iegūšanai krimināllietās” (COM/2018/225 final, 2018). Minētajā dokumentā uzsvērts, ka šā priekšlikuma mērḳis ir uzlabot juridisko noteiktību iestādēm, pakalpojumu sniedzējiem un iesaistītajām personām, kā arī saglabāt augstus standartus tiesībaizsardzības pieprasījumiem, tādējādi nodrošinot pamattiesību aizsardzību, pārredzamību un atbildību. Minētā Regula paredz ieviest jaunus e-pierādījumu sniegšanas un saglabāšanas rīkojumus, kuri balstīsies uz savstarpējās atzišanas principiem. Jebkurā krimināllietā ar tiem varēs pieprasīt tikai abonenta un noslodzes datus. Savukārt, lai iegūtu darījuma vai satura datus, rīkojumu tiesa varēs izdot tikai par nodarïjumiem, kur soda maksimālais apmērs izdevējvalstī ir ne mazāks par trim gadiem, vai par noziegumiem, kuri saistiti ar terorismu.

İpaši uzsverot, ka Regulas priekšlikums tiek gatavots tā, lai atbilstu KNK, nepieciešams apskatīt arī ES kā organizācijas iesaisti KNK otrā papildu protokola izstrādes procesā. Kaut arī KNK neparedz, ka ES varētu pievienoties šim līgumam, ES piedalās arī Kibernoziegumu konvencijas otrā protokola izstrādes procesā kā novērotāja organizācija, jo no 62 KNK dalībvalstīm 26 ir ES dalībvalstis. Respektīvi, tās dalībnieki ir visas valstis, izṇemot Īriju un Zviedriju, kas turpina sarunas par pievienošanos KNK. Eiropas Komisija uzskata, ka saskañā ar LEZD 3. panta 2. punktu (Līgums par Eiropas Savienības darbību) tās kompetencē ir arī noslēgt starptautisku līgumu "tiktāl, ciktāl līguma slēgšana ietekmē Savienības kopīgos noteikumus vai maina to jomu". Tādējādi darbu pie KNK otrā papildu protokola ES uzskata par tādu, kas nākotnē var būtiski ietekmēt arī ES kopīgos noteikumus. Eiropas Komisijas sarunu mandātā (COM(2019) 71 final, 2019) ir ietverta arī diskusija par starptautiskiem e-pierādījumu sniegšanas rīkojumiem, paplašinātu meklēšanu un piekḷuvi, kas iespējama, pamatojoties uz pārmeklējamās sistēmas akreditācijas datiem. 
Uldis Kinis, Nikita Sinkevičs. Automatizētās datu apstrādes sistēmā esošo datu kontrole

(Kriminālprocesa likuma 219. pants): nacionālie un starptautiskie piemērošanas aspekti

\section{Valsts policijas priekšlikuma satura izvērtējums}

VP priekšlikums ir veikt grozījumus KPL 219. panta otrajā daḷā, svītrojot vārdus "Latvijas teritorijā esošā" un izsakot normu šādā redakcijā: "Ja ir pamats uzskatīt, ka meklētie dati (informācija) tiek uzglabāti citā sistēmā, kurai var piekḷūt autorizēti, izmantojot izmeklēšanas tiesneša lēmumā minēto sistēmu, jauns lēmums nav nepieciešams." Priekšlikuma autori norāda, ka minētā norma nav grozìta kopš 2005. gada un ka likumdevējs, pieṇemot šādu normu, nevarēja paredzēt tehnologiju un informācijas pakalpojumu transformāciju, proti, ka ADAS vai tās dal̦a vairs nav saistāma ar konkrētas valsts teritoriju - tā var atrasties jebkurā valstī, bieži vien neidentificētā. Vēl vairāk, izmeklēšanas laikā gandrīz neesot iespējams identificēt un pierādīt, ka noteiktā ADAS dal̦a, kurai var piekḷūt autorizēti, atrodas Latvijas vai citas valsts teritorijā. Turklāt gan procesa virzītājs, gan tiesnesis, gan pat kontrolējamā persona varot arī nezināt, kur fiziski atrodas viṇu rīcībā neesošas attālinātas piekḷuves automatizētās datu apstrādes sistēmas dalıs.

Līdz ar to VP uzskata, ka mūsdienu pasaulē informācijas tehnologijas un to risinājumi vairs nav saistāmi ar konkrētu valsts teritoriju, tāpēc, lai efektivizētu KPL 219. panta normas piemērošanu, nepieciešams atteikties no norādes, ka tā attiecināma tikai uz Latvijas teritoriju. Papildu priekšlikuma pamatojumam VP izmanto 2019. gada 28. marta Norvēgijas Augstākās tiesas nolēmumu (Supreme Court of Norway, 2019), kur tiesa atzinusi, ka policijai ir tiesības Oslo Tidal Music AS ADAS pārmeklēt un izṇemt arī datus, kas tiek uzglabāti ADAS ārpus Norvēgijas. Lai izvērtētu minēto spriedumu, būtu nepieciešama plašāka analīze, taču interesants ir apstāklis, ka tiesa, analizējot Kibernoziegumu konvenciju, analizē tikai KNK 18. pantu, kas tiešām nosaka minimumu, kas valstij jāizpilda, pievienojoties Konvencijai, bet neanalizē Konvencijas Starptautiskās sadarbības dalı, konkrēti 32. panta b punktu, kas nevis nosaka minimumu, bet gan strikti reglamentē piel̦aujamos pārrobežu pārmeklējamos gadijjumus, ja dati pieejami no pārmeklēšanai pakḷautās sistēmas. Tādēl var secināt, ka argumenti, ko tiesa izmantojusi šāda viedokḷa taisīšanai, ir vairāk balstīti uz nacionālām interesēm, nevis uz starptautisku avotu analīzi.

No priekšlikuma pamatojuma var izdalīt divas tiesiskās situācijas. Pirmā, kad no pārmeklējamās sistēmas iespējams ar esošajiem identifikatoriem iegūt datus, kuru teritoriālo piederību nav iespējams noskaidrot, piemēram, dati, kas atrodas Dark web vai citos šifrētos interneta resursos. Šajā gadījumā var tikt piemērota prezumpcija, ka šie dati atrodas ārpus jebkādas jurisdikcijas, līdz ar to nav pakḷauti nevienai jurisdikcijai, un valsts policijai ir likumīga pieeja šiem datiem pat bez speciālu normu grozī̌anas. Otrā, kad, pārmeklējot sistēmu, ir skaidrs, ka dati atrodas pie konkrēta pakalpojuma sniedzēja, kurš darbojas un kura infrastruktūra (fiziskā, log̣iskā) atrodas citas valsts teritorijā, kas atbilstoši Tallinn Manual ekspertu viedoklim ir pakḷauti tās valsts, kurā tie atrodas, suverenitātei. Lìdz ar to izmeklēšanas darbība ir piel̦aujama tiktāl, ciktāl tā neaizskar citu starptautisku tiesību subjektu suverenitāti un tiesības uz jurisdikciju. 
Uldis Kinis, Nikita Sinkevičs. Automatizētās datu apstrādes sistēmā esošo datu kontrole (Kriminālprocesa likuma 219. pants): nacionālie un starptautiskie piemērošanas aspekti

\section{Secinājumi}

1. Kriminālprocesa likuma 219. pants "Automatizētās datu apstrādes sistēmā esošo datu kontrole" ir ieviests, lai Latvija varētu pievienoties KNK. Līdz ar to tā saturs ir atklājams tikai kopsakarībā ar KNK 19. pantu un KNK Paskaidrojošã ziṇojuma tekstu, kas uzskatāms par oficiālu KNK teksta interpretācijas līdzekli. Tā kā nekādi citi starptautiski dokumenti par datu pārmeklēšanu un izṇemšanu nav pieñemti, jāsecina, ka pēc būtības nekas šì panta saturā no KNK pien̦emšanas brīža nav mainījies, jo arī 2001. gadā bija pārrobežu informācijas pakalpojumu pieejamība.

2. Minētais pants ir iekḷauts KNK 2. sadaḷā, kur noteikti minimālie pasākumi, kas dalībvalstīm jāveic, lai efektivizētu kibernoziegumu apkarošanu dalībvalsts teritorijā. KNK PZ ir speciāli uzsvērts, ka šo instrumentu nevar izmantot, lai veiktu pārrobežu sistēmu pārmeklēšanu. Savukārt starptautisko sadarbību, tostarp izpildot dalībvalstu lūgumus veikt sistēmu pārmeklēšanu, datu izṇemšanu un pārrobežu datu pieejamību, kuri pieejami, izmantojot pārmeklējamā sistēmā esošos identifikatorus, var veikt tikai KNK 31. un 32. pantā noteiktajos gadījumos. Turklāt šis uzskaitïjums bez papildu starptautiskās vienošanās nav paplašināms.

3. Kibernoziegumu jurisdikcijas kodolu, kā tas ir noteikts KNK 22. pantā, noteic valstu teritorialitāte un suverenitāte. Turklāt lielākā dą̧a ekspertu uzskata, ka suverenitāte ir attiecināma arī uz valsts teritorijā esošo kiberinfrastruktūru (tehnisko, logisko un sociālo līmeni). Taču, kā norādìts iepriekš citētajā Tallinn Manual 2.0, suverenitāte uzliek dalībvalstīm arī pienākumus apkarot kibernoziegumus, lai nepiel̦autu kaitējuma nodarīšanu citu valstu subjektiem un objektiem.

4. Apkopojot salīdzinošā pētijuma rezultātus, var secināt, ka valstīm, kuras ir ratificējušas KNK, ir dažādas pieejas attiecībā uz datu kontroli ārvalstu ADAS. Piemēram, Vācijas, Zviedrijas, Austrijas u. c. valstu normatīvie akti nedod tiesības piekḷūt ārvalstu ADAS datiem, savukārt Spānijas, Portugāles un Rumānijas normatīvie akti tādu iespēju pielauj. Tāpat jāatzīmē, ka atsevišķu valstu krimināltiesiskajos regulējumos nav iestrādāta norāde uz pārmeklējamo datu teritoriālo atrašanās vietu. Tas viss liecina par valstu dažādām pieejām KNK normu interpretācijā.

5. Izvērtējot Valsts policijas priekšlikumu par KPL 219. panta otrās daḷas groziššnu, autori uzskata, ka ir vērtējamas divas juridiskas situācijas: pirmā - kad no pārmeklējamās sistēmas iespējams ar esošajiem identifikatoriem iegūt datus, kuru teritoriālo piederību nav iespējams noskaidrot. Šajā gadījumā var tikt piemērota prezumpcija, ka dati, kas atrodas ārpus jebkādas jurisdikcijas, nav pakḷauti nevienai citas valsts jurisdikcijai. Lìdz ar to procesa virzītājam ir likumīga pieeja šiem datiem pat bez KPL 219. panta normu grozišanas. Otrā situācija - ja procesa virzītājam ir zināms, ka dati atrodas citā jurisdikcijā esošã sistēmā, tad procesa virzītājs var piemērot jurisdikciju tiktāl, ciktāl tā nepārkāpj citu starptautisko tiesību subjektu teritorialitāti un suverenitāti. 
Uldis Kinis, Nikita Sinkevičs. Automatizētās datu apstrādes sistēmā esošo datu kontrole

(Kriminālprocesa likuma 219. pants): nacionālie un starptautiskie piemērošanas aspekti

\section{Control of Data Located in Automated Data Processing Systems: National and International Application Aspects}

\section{Abstract}

The article "Control of Data Located in Automated Data Processing Systems: National and International Application Aspects" is the result of the idea initiated by the proposal submitted by the Latvian State Police, to the Permanent Working Group of Criminal Procedure Experts of the Ministry of Justice regarding the amendment of Section 219, Paragraph 2 of the Criminal Procedure Law. Article 219 of the Criminal Procedure Law "Control of Data in an Automated Data Processing System" is essentially analogous to Article 19 of the Cybercrime Convention, which obliges Member States to adopt such legislation as to facilitate the search of data in systems located within their territory.

The essence of the proposal is to renounce the national territorial application clause in the Article, as it restricts the police operability to obtain evidence in criminal proceedings in situations where data stored in another computer systems are located outside of the territory of Latvia but are legally accessible from searchable system via Internet. In other words, to change the scope of jurisdiction of search and seizure to transborder search and seizure.

The debate on whether one Member State is entitled to search and capture data in a system located in the territory of another Member State, is not new. It has been running since the adoption of the Convention and it is believed it will continue at least until the adoption of the Second Additional Protocol to the Convention, which should address issues related to cybercrime investigations.

In the article, the authors will analyse what and how the situation has fundamentally changed since the adoption of the Cybercrime Convention and the Criminal Procedure Law, especially regarding the understanding of jurisdiction in the application of criminal procedural instruments. The authors also aim to provide their solutions for solving problems in relation with the proposal submitted by the State Police.

Keywords: control of data, automated data processing systems, cybercrime convention, evidence in criminal proceedings, sovereignty, criminal jurisdiction, data search and seizure.

\section{Avoti un literatūra}

1. Bazy-Malaurie, C. 2018. The digital world: what relationship between the jurisdictions? In: The Role of Constitutional Courts in the Globalised World of the 21st Century. Proceedings of the 2018 Conference of the Constitutional Court of the Republic of Latvia. Riga: Latvijas Republikas Satversmes tiesa. 
Uldis Kinis, N̦ikita Sinkevičs. Automatizētās datu apstrādes sistēmā esošo datu kontrole (Kriminālprocesa likuma 219. pants): nacionālie un starptautiskie piemērošanas aspekti

2. Bundesministeriums der Justiz und für Verbraucherschutz. 03.12.2020. Strafprozeßordnung. Iegūts no: https://www.gesetze-im-internet.de/stpo/BJNR006290950.html

3. EUR-Lex. 2015. Eiropas Drošības programma - COM(2015) 185 final. Iegūts no: https:/leur-lex. europa.eu/legal-content/LV/TXT/HTML/?uri=LEGISSUM:230801_2

4. EUR-Lex. 2019. Eiropas Komisija. Ieteikums. Padomes lēmums, ar ko pilnvaro piedalìties sarunās par otro papildu protokolu Eiropas Padomes Konvencijai par kibernoziegumiem (Eiropas Padomes lìgumu sērija Nr. 185). Iegūts no: https://eur-lex.europa.eu/resource.html?uri=cellar:8d1e03fe2939-11e9-8d04-01aa75ed71a1.0016.02/DOC_1\&format=PDF

5. EUR-Lex. 2018. Priekšlikums. Eiropas Parlamenta un Padomes Regula. Par Eiropas elektronisko pierādījumu sniegšanas un saglabāšanas rīkojumiem elektronisko pierādījumu gūšanai krimināllietās. Iegūts no: https://eur-lex.europa.eu/legal-content/LV/TXT/HTML/?uri=CELEX:520 18PC0225\& from $=\mathrm{LV}$

6. Council of Europe. 1959. European Convention on Mutual Assistance in Criminal Matters. ETS No.030. Strasbourg.

7. Council of Europe. 1990. Computer-Related Crime. Recomendation No. R (89) 9 on computerrelated crime and final report of the European Committe on Crime Problems. Iegūts no: http:// www.oas.org/juridico/english/89-9\&final\%20Report.pdf

8. Council of Europe. 1995. Recommendation R(95)13 concerning problems of criminal procedure law connected with information technology. Iegūts no: https://rm.coe.int/ CoERMPublicCommonSearchServices/DisplayDCTMContent?documentId=09000016804f6e76

9. Council of Europe. 2001. Convention on Cybercrime. Iegūts no: https://rm.coe.int/1680081561

10. Council of Europe. 2001. Explanatory Report to the Convention on Cybercrime. Iegūts no: https:// rm.coe.int/16800cce5b

11. Council of Europe. 16.09.2016. Criminal justice access to electronic evidence in the cloud: Recommendations for consideration by the T-CY. Final report of the T-CY Cloud Evidence Group. Iegūts no: https://rm.coe.int/CoERMPublicCommonSearchServices/DisplayDCTMContent?d ocumentId=09000016806a495e

12. Council of Europe. 2017. T-CY Guidance note \# 10 Production orders for subscriber information.

13. Council of Europe. 21.12.2020. Chart of signatures and ratifications of Treaty 185. Iegūts no: https://www.coe.int/en/web/conventions/full-list/-/conventions/treaty/185/signatures?.p_ auth $=$ zCdleT3v

14. Elektronisko sakaru likums: Latvijas Republikas likums: pieṇemts 28.10.2004. un stājās spēkā 01.12.2004. Latvijas Vèstnesis. 183, 17.11.2004.

15. European Commission. 1996. Illegal and harmful content on the Internet. Iegūts no: https:// eur-lex.europa.eu/LexUriServ/LexUriServ.do?uri=COM:1996:0487:FIN:en:PDF

16. Federal Foreign Office. 2020. Digital Sovereignty. Iegūts no: https://erstelesung.de/wp-content/ uploads/2020/10/20-10-14_Germany_EU_Digital-Sovereignty.pdf

17.Federal Foreign Office. 2020. Expanding the EU's digital sovereignty. Iegūts no: https://www. eu2020.de/eu2020-en/eu-digitalisation-technology-sovereignty/2352828

18. Floridi, L. 12.08.2020. The Fight for Digital Sovereignty: What It Is, and Why It Matters, Especially for the EU. Iegūts no: https://link.springer.com/article/10.1007\%2Fs13347-020-00423-6

19. Henriksen, A. 22.01.2019. The end of the road for the UN GGE process: The future regulation of cyberspace. Journal of Cybersecurity. 5(1). Iegūts no https://doi.org/10.1093/cybsec/tyy009

20. Kancelaria Sejmu. 2020. Kodeks postępowania karnego. Iegūts no: https://isap.sejm.gov.pl/isap. nsf/download.xsp/WDU19970890555/U/D19970555Lj.pdf 
Uldis Kinis, N̦ikita Sinkevičs. Automatizētās datu apstrādes sistēmā esošo datu kontrole (Kriminālprocesa likuma 219. pants): nacionālie un starptautiskie piemērošanas aspekti

21. Komaitis, K. 07.09.2020. Europe's pursuit of digital sovereignty could affect the future of the Internet. TECH.EU. Iegūts no: https://tech.eu/features/32780/europe-digital-sovereignty/

22. Koops, B. J. (ed). 2006. Cybercrime and jurisdiction. T. M. C. Asser Press.

23. Kriminālprocesa likums: Latvijas Republikas likums: pieṇemts 21.04.2005. un stājās spēkā 01.10.2005. Latvijas Vēstnesis. 74, 11.05.2005.

24. Kinis, U. 2015. Kibernoziedzība, kibernoziegumi un jurisdikcija. Rīga: Jumava.

25. Legicoop. 2020. https://www.gip-jci-justice.fr/en/projects/intra-european/legicoop-networkfor-legislative-cooperation-between-the-ministries-of-justice-of-the-european-union

26. Legifrance. 2020. Code de procédure pénale. Iegūts no: https://www.legifrance.gouv.fr/codes/ section_lc/LEGITEXT000006071154/LEGISCTA000006167524/\#LEGISCTA000038311671

27. Lieljuksis, A. 2019. 219. pants. Automatizētās datu apstrādes sistēmā esošu datu kontrole. No: Strada-Rozenberga, K., red. Kriminālprocesa likuma komentāri. A daḷa. Rīga: Latvijas Vēstnesis.

28. Lietuvos Respublikos Seimas. 19.12.2020. Baudžiamojo proceso kodeksas. Iegūts no: https:/eseimas.lrs.lt/portal/legalAct/lt/TAD/TAIS.163482/asr\#part_7ca4d122f6c8443f8d18e908c735 dcde

29. LOVDATA. 04.12.2020. Straffeprosessloven. Iegūts no: https://lovdata.no/dokument/NL/ lov/1981-05-22-25/*\#\&\#x2a

30. Madiega, T. 2020. Digital sovereignty for Europe. European Parliamentary Research Service. Iegūts no: https://www.europarl.europa.eu/RegData/etudes/BRIE/2020/651992/EPRS_ BRI(2020)651992_EN.pdf

31. Meikališa, A. 2019. 179. pants. Kratīšana. No: Strada-Rozenberga, K., red. Kriminālprocesa likuma komentāri. A daḷa. Rīga: Latvijas Vēstnesis.

32. 32. Pravno-informacijski sistem. 01.01.1995. Zakon o kazenskem postopku. Iegūts no: http:// www.pisrs.si/Pis.web/pregledPredpisa?id=ZAKO362\#

33. Procuradoria-Geral Distrital de Lisboa. 15.12.2009. Lei do Cibercrime. Iegūts no: http://www. pgdlisboa.pt/leis/lei_mostra_articulado.php?nid=1137\&tabela=leis

34. Rechtsinformationssystem des Bundes. 21.12.2020. Strafprozeßordnung 1975. Iegūts no: https:// www.ris.bka.gv.at/GeltendeFassung.wxe?Abfrage=Bundesnormen\&Gesetzesnummer $=10002326$

35. Riigi Teataja. 07.05.2020. Kriminaalmenetluse seadustik. Iegūts no: https://www.riigiteataja.ee/ akt/119032015022?leiaKehtiv\#para126b7

36. Schmitt, M. N. (ed). 2017. Tallinn Manual 2.0 on the International Law Applicable to Cyber Operations. Cambridge: Cambridge University Press.

37.Strada-Rozenberga, K. 2019. 3. pants. Kriminālprocesa spēks telpā. Strada-Rozenberga, K., red. Kriminālprocesa likuma komentāri. A daḷa. Rīga: Latvijas Vēstnesis.

38. Supreme Court of Norway. 28.03.2019. HR-2019-610-A (case no. 19-010640STR-HRET), criminal case. Iegūts no: no https:/www.domstol.no/globalassets/upload/hret/decisions-in-english-translation/hr-2019-610-a.pdf

39. Svantesson, D. J. 2015. A new jurisprudential framework for jurisdiction: beyond the Harvard Draft. Iegūts no: https://core.ac.uk/download/pdf/205332442.pdf

40. Svantesson, D. J. 2017. Solving the Internet Jurisdiction Puzzle. Oxford: Oxford University Press.

41. United Nations. 1948. Charter of the United Nations. Iegūts no: https://www.un.org/en/sections/ un-charter/chapter-i/index.html 
Uldis Kinis, N̦ikita Sinkevičs. Automatizētās datu apstrādes sistēmā esošo datu kontrole (Kriminālprocesa likuma 219. pants): nacionālie un starptautiskie piemērošanas aspekti

42. Ziemele, I. 2019. Constitutional courts as lock-gates in the globalized world. In: The Role of Constitutional Courts in the Globalised World of the 21st Century. Iegūts no: https:/www.satv. tiesa.gov.lv/other/2019-ST-Referati-2018-atverumos.pdf

43. Наказателно-проиесуален кодекс. 2020. Iegūts no: https://www.lex.bg/laws/ldoc/2135512224 44. Татаринов, М. 2019. Пространственное Аействие уголовной юрисАикции. Межљународное право. Iegūts no: https://nbpublish.com/library_read_article.php?id=29545 [sk. 20.12.2020.]. 45. Уголовный процессуальный кодекс. 21.07.2020. Iegūts no: http://continent-online.com/ Document/?doc_id=31197178\#pos=5;-142 